\title{
Accreting coral reefs in a highly urbanized environment
}

\author{
Fraser A. Januchowski-Hartley ${ }^{1}$ (D) Andrew G. Bauman $^{2}$ (D) Kyle M. Morgan $^{3}$ (D) \\ Jovena C. L. Seah ${ }^{2}$ (D) Danwei Huang ${ }^{2}\left(\right.$ D) $\cdot$ Peter A. Todd $^{2}($ )
}

Received: 29 November 2019/ Accepted: 6 May 2020/Published online: 20 May 2020

(C) The Author(s) 2020

\begin{abstract}
Globally, many coral reefs have fallen into negative carbonate budget states, where biological erosion exceeds carbonate production. The compounding effects of urbanization and climate change have caused reductions in coral cover and shifts in community composition that may limit the ability of reefs to maintain rates of vertical accretion in line with rising sea levels. Here we report on coral reef carbonate budget surveys across seven coral reefs in Singapore, which persist under chronic turbidity and in highly disturbed environmental conditions, with less than $20 \%$ light penetration to $2 \mathrm{~m}$ depth. Results show that mean net carbonate budgets across Singapore's reefs were relatively low, at $0.63 \pm 0.27 \mathrm{~kg} \quad \mathrm{CaCO}_{3} \quad \mathrm{~m}^{-2} \mathrm{yr}^{-1}$ (mean $\pm 1 \mathrm{SE}$ ) with a range from -1.56 to 1.97 , compared with the mean carbonate budgets across the IndoPacific of $1.4 \pm 0.15 \mathrm{~kg} \mathrm{CaCO}_{3} \mathrm{~m}^{-2} \mathrm{yr}^{-1}$, and isolated Indian Ocean reefs pre-2016 bleaching $\left(\sim 3.7 \mathrm{~kg} \mathrm{CaCO}_{3}\right.$
\end{abstract}

Topic Editor Ian C. Enochs

Fraser A. Januchowski-Hartley and Andrew G. Bauman have contributed equally to this study.

Electronic supplementary material The online version of this article (https://doi.org/10.1007/s00338-020-01953-3) contains supplementary material, which is available to authorized users.

Fraser A. Januchowski-Hartley

f.a.hartley@swansea.ac.uk

1 Department of Biosciences, College of Science, Swansea University, Swansea, UK

2 Experimental Marine Ecology Laboratory, Department of Biological Sciences, National University of Singapore, Singapore 117558, Singapore

3 Asian School of the Environment, Nanyang Technological University, Singapore 637459, Singapore $\mathrm{m}^{-2} \mathrm{yr}^{-1}$ ). Of the seven reefs surveyed, only one reef had a net negative, or erosional budget, due to near total loss of coral cover $(<5 \%$ remaining coral). Mean gross carbonate production on Singapore's reefs was dominated by stresstolerant and generalist species, with low-profile morphologies, and was $\sim 3 \mathrm{~kg} \mathrm{~m}^{-2} \mathrm{yr}^{-1}$ lower than on reefs with equivalent coral cover elsewhere in the Indo-Pacific. While overall these reefs are maintaining and adding carbonate structure, their mean vertical accretion potential is below both current rates of sea level rise (1993-2010), and future predictions under RCP 4.5 and RCP 8.5 scenarios. This is likely to result in an increase of $0.2-0.6 \mathrm{~m}$ of water above Singapore's reefs in the next $80 \mathrm{yr}$, further narrowing the depth range over which these reefs can persist.

Keywords Bioerosion - Carbonate budget - Reef growth Singapore $\cdot$ Urbanization

\section{Introduction}

Coral reefs and their associated biodiversity are heavily dependent on the sustained maintenance of complex threedimensional reef framework through coral growth (Perry et al. 2008; Graham and Nash 2013). The net balance between the biological production of calcium carbonate by reef communities and biological erosion of the reef framework-the coral reef carbonate budget (Perry et al. 2008)-underpins the accretionary potential of reef ecosystems. While the continuing loss of live coral cover on reefs is a major threat to future reef growth (Manzello et al. 2008; Kennedy et al. 2013; Perry and Morgan 2017), changes in coral species composition and increasing abundance of bioeroding groups (e.g. Perry et al. 2014; Januchowski-Hartley et al. 2017) can also negatively 
influence carbonate budgets. For example, on Caribbean reefs, shifts in coral communities to dominance by nonframework building genera, such as Siderastrea and plating Agaracia from massive Orbicella and branching Acropora species, have dramatically reduced gross carbonate production (Perry et al. 2015a). Within the Indian Ocean, similar ecological transitions have also been observed due to the post-bleaching loss of Acropora (Perry and Morgan 2017; Lange and Perry 2019), and increased biomass of eroding parrotfishes that may have subsequently tied these reefs into negative budgetary states (Januchowski-Hartley et al. 2017; Perry and Morgan 2017).

Globally, coastal zones are experiencing rapid urbanization (Dsikowitzky et al. 2016; Todd et al. 2019) and human population growth (Small and Nicholls 2003) which has degraded many nearshore ecosystems, including coral reefs (Heery et al. 2018). Urbanized reef systems are characterized by altered coral communities (Guest et al. 2016; Heery et al. 2018) in response to the extreme abiotic conditions (e.g. elevated turbidity, high sedimentation), with shifts to sediment-tolerant morphologies (e.g. domed growth forms and mushroom corals) (Bongaerts et al. 2012), and a dominance of stress-tolerant and generalist coral taxa (Chow et al. 2019). Although there is evidence that high turbidity may reduce the impacts of prolonged heat stress (Cacciapaglia and van Woesik 2016; Morgan et al. 2017; Sully and van Woesik 2020), and that some reefs can thrive under such conditions (Browne et al. 2013; Morgan et al. 2016a), very high levels of suspended particulate matter can restrict the maximum depth range of reefs in urbanized environments (i.e. reef compressionthe decline in bathymetric range to a narrow depth band, Morgan et al. 2016; Heery et al. 2018). Much of our recent knowledge of how Indo-Pacific carbonate budgets respond to disturbance comes from investigations of remote oceanic reef systems with low human population densities, such as Chagos (Perry et al. 2015b; Lange and Perry 2019), Seychelles (Januchowski-Hartley et al. 2017), the Maldives (Perry and Morgan 2017; Ryan et al. 2019), and Micronesia (van Woesik and Cacciapaglia 2018, 2019). In contrast, few studies on contemporary reef growth rates have been conducted on Indo-Pacific reefs associated with high levels of terrestrial influences (but see Edinger et al. 2000; Browne et al. 2013). Therefore, the implications of shifts in reef communities to slower-growing and stresstolerant species on carbonate production and reef construction have not been directly addressed. Urbanized reefs have become dominated by slower-growing and stresstolerant species, which may confer some resilience to future impacts (Guest et al. 2016; Heery et al. 2018; Todd et al. 2019). Because similar trends in community composition may be occurring on non-urbanized reefs (e.g. Perry et al. 2015a; Darling et al. 2019), urbanized reef carbonate budgets may be the forerunners of carbonate budget states of coastal reefs, even non-urbanized reefs, in the future.

Coral reefs in Singapore provide a unique opportunity for investigating reef carbonate budgets in a highly disturbed, urbanized equatorial reef environment. Situated on the western edge of the Indo-Pacific Coral Triangle, coral communities in Singapore have experienced decades of chronic anthropogenic disturbance. Extensive coastal development, land reclamation and large-scale shipping activities have resulted in high levels of sedimentation, turbidity and eutrophication that exceed conditions on most tropical reefs (Erftemeijer et al. 2012; Browne et al. 2015; Heery et al. 2018). Combined, these local stressors have reduced the total area of living reefs in Singapore by over $60 \%$ between 1953 and 2012, from 40 to $13.25 \mathrm{~km}^{2}$ (Tun 2012). Moreover, Singapore's reefs have been impacted by multiple severe bleaching events due to climate change (Guest et al. 2012; Chou et al. 2016). Despite these adverse conditions, diverse coral communities still exist, and overall mean live coral cover remains relatively high (Guest et al. 2016; Wong et al. 2018). However, most coral communities in Singapore are dominated by slow-growing stress-tolerant taxa (e.g. massive Porites and Platygyra) or generalist taxa (e.g. foliose or submassive Merulina, Pachyseris and Echinopora) that tend to provide lower structural complexity (Guest et al. 2016), while fast growing, structurally complex tabular or branching corals are uncommon (e.g. Acropora; Huang et al. 2009; Guest et al. 2016). Although there are many indicators of the negative effects of urbanization on Singapore's coral communities, no work has examined whether these reefs are accreting or eroding. Here we estimated the first coral reef carbonate budget for this highly disturbed urbanized reef environment. Our objectives were to: (1) estimate reef carbonate budgets in Singapore and compare them to coral reefs in non-urbanized reef locations where conditions for coral growth are more favourable; (2) investigate the relationships between coral cover, life histories and morphology for reef carbonate production; and (3) estimate reef accretion potential for Singapore reefs, and how this may influence reef compression (Heery et al. 2018) under different sea level rise scenarios.

\section{Materials and methods}

\section{Study area}

We studied seven offshore coral reefs (Terumbu Pempang Tengah, Pulau Satumu, Pulau Hantu, Pulau Semekau, Pulau Jong, Sisters' Island, and Kusu Island) located among the southern islands of Singapore (Fig. 1). 


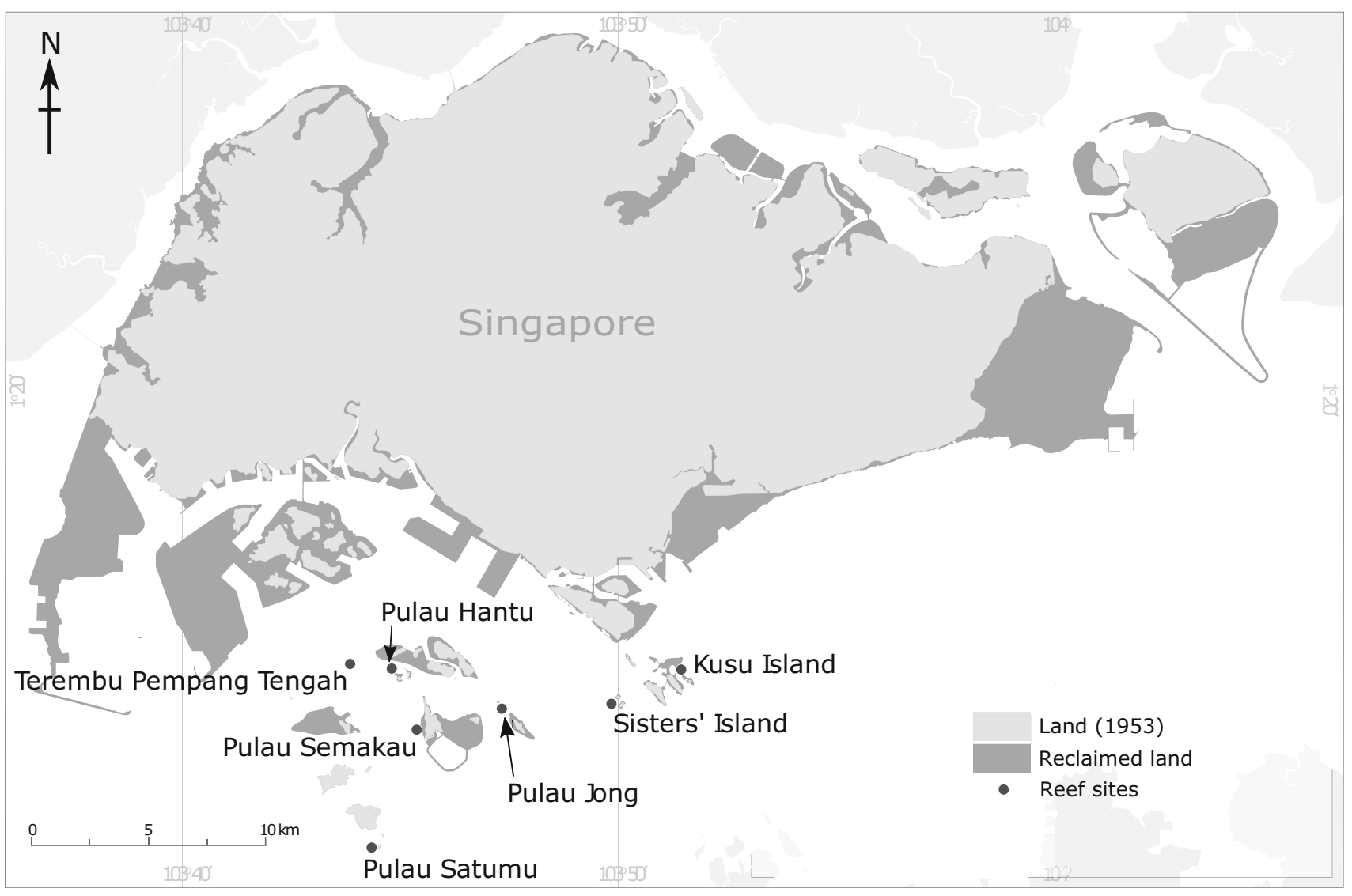

Fig. 1 Map of southern islands of Singapore showing study reefs

Singapore is a city state of approximately 5.7 million people, which consists of one main island and $\sim 45$ smaller offshore islands (Tun 2012) (Fig. 1). Most of these offshore islands have well-developed fringing reefs characterized by a shore-adjacent reef flat leading seaward to the reef crest and down the reef slope to $\sim 8 \mathrm{~m}$ depth, with the exception of Terumbu Pempang Tengah which is a patch reef and not associated with an island. Most reef growth in Singapore is limited to a relatively narrow zone between the reef crest and upper reef slope from 3 to $6 \mathrm{~m}$ depth (Guest et al. 2016). This depth restriction (i.e. 'reef compression' sensu Heery et al. 2018) is primarily attributed to domination of the upper reef flats $(0-2 \mathrm{~m})$ by fleshy macroalgae (e.g. Sargassum Low et al. 2019), and extreme light attenuation with increasing depth $(>8 \mathrm{~m})$ due to high levels of suspended sediments (Chow et al. 2019). Within each reef, we conducted benthic, parrotfish and urchin surveys, and deployed plastic settlement substrates to measure rates of crustose coralline algae (CCA) production. Additionally, we deployed bioerosion assays $(7 \mathrm{~cm}$ diameter $\times \sim 12 \mathrm{~cm}$ length cores of massive Porites skeletal structure) to estimate internal bioerosion on five reefs (Pulau Satumu, Pulau Hantu, Pulau Semekau, Pulau Jong and Kusu Island). Survey efforts were confined to the leeward side of all reefs, with the exception of Kusu Island, which was conducted on the semi-exposed north-eastern side of the island, and conducted during October and November 2017.

\section{Carbonate budget surveys}

We conducted benthic surveys on each reef using six replicate $10 \mathrm{~m}$ line-intercept transects spaced $\sim 5 \mathrm{~m}$ apart following Indo-Pacific ReefBudget methods (Perry et al. 2018a). This method measures the size and morphology of each individual colony along the transect, and uses colony size, simple geometric relationships and published genera specific mean extension rates $\left(\mathrm{cm} \mathrm{yr}^{-1}\right)$ and skeletal density $\left(\mathrm{g} \mathrm{cm}^{-3}\right)$ to calculate carbonate production rates in $\mathrm{kg}$ $\mathrm{CaCO}_{3} \mathrm{~m}^{-2} \mathrm{yr}^{-1}$ (all rates available at http://www.geo graphy.exeter.ac.uk/reefbudget; Perry et al. 2018a). While there are published growth rates for some coral genera from Singapore, including Merulina ampliata (Dikou 2009) and Porites spp. (Tanzil et al. 2013), and skeletal density for several species ( $\mathrm{Ng}$ et al. 2019) there is a paucity of data for most coral genera. Here we used the published ReefBudget rates for the Indo-Pacific in lieu of Singapore-specific rates for the majority of genera, with the 
exception of Merulina and Porites growth. Similarly, although we have used the intra-species range of skeletal densities in Ng et al. (2019) where possible (Table S1), we note the median density for most species was comparable to ReefBudget reported densities. To estimate rates of CCA carbonate production, we deployed settlement cards at each reef from August 2017-March 2018 and March 2018-September 2018, following methods from Perry et al. (2018a). See electronic supplementary material for full methodological details (Fig. S1; Table S2).

Within each reef, we surveyed transects at 3-4 m depth, parallel to the upper reef slope, and benthic groups across the entire 3-dimensional surface underneath the tape, including overhangs, vertical and horizontal surfaces, and crevices were measured to the nearest centimetre. Benthic groups measured were: scleractinian (hard) corals to genera and morphology, crustose coralline algae (CCA), epilithic algal matrix (EAM sensu Wilson et al. 2003), soft corals, sponges, fleshy and calcareous macroalgae, sediment, rubble, bare substrate (i.e. limestone pavement), and other benthic organisms (e.g. ascidians, zooanthids, etc.). Rugosity was calculated for each transect by dividing the total 3-dimensional reef surface by the linear distance (i.e. the rugosity of a flat surface equals 1 ).

To estimate external bioerosion rates, we conducted separate parrotfish and urchin surveys within each reef in the same area as the benthic surveys. We estimated parrotfish species-size abundance using a series of timed swims in June 2017. We conducted three censuses on each reef, with adjacent censuses separated by a minimum of $10 \mathrm{~m}$ following methods by Hoey and Bellwood (2009). Each census consisted of a diver (AGB) swimming at a constant speed and depth (3-4 m) parallel to the upper reef slope for 5-min and recording all parrotfish species and sizes greater than $10 \mathrm{~cm}$ total length (TL) within a $2.5-\mathrm{m}-$ wide transect that extended from the reef substratum to the surface of the water. Care was taken not to double count parrotfish that left and subsequently re-entered the survey area. We selected timed swims and transect width because of the generally poor diving conditions (visibility $<3 \mathrm{~m}$ ) in Singapore (Bauman et al. 2017), and to minimize observer effects (Hoey and Bellwood 2009). Urchin abundance, test diameter (in $2 \mathrm{~cm}$ increments) and species composition were recorded within six $10 \mathrm{~m} \times 2 \mathrm{~m}$ belt transects along the same ReefBudget transects on each reef. Urchin test diameter and species are directly related to erosional capacity of urchins from the family Diadematidae (three species of which are common on Singapore reefsDiadema setosum, Diadema savignyi and Echinothrix diadema), with larger individuals having exponentially higher erosion rates (Perry et al. 2018a). We combined census data with published carbonate ingestion rates from the literature and adjusted transect area to account for rugosity and substratum cover, to yield a measure of erosion rates. Rates of internal erosion were estimated across five reefs in Singapore (Pulau Hantu, Pulau Satumu, Pulau Semakau, Pulau Jong and Kusu Island; Fig. 1) using standardized Porites coral cores deployed from April 2018 to April 2019. See electronic supplementary material for full details (Table S3).

\section{Reef accretion potential}

Vertical reef accretion potential (RAP) was calculated following Perry et al. (2015b, 2018b), which converts transect specific net carbonate production rates to a vertical reef accretion potential (RAP). This approach accounts for variation in reef framework porosity based on dominant coral community morphologies, and reef-derived sediment reincorporation rates based on levels of bioerosion (Smith and Kinsey 1976). A porosity value of $70 \%$ void space was used for branching coral assemblages because most branching corals observed in this study on Singapore reefs have closely branched morphologies, while $20 \%$ porosity values were used for massive and encrusting coral dominated communities, and 50\% for mixed coral assemblages (see Perry et al. 2018b). Reef-derived sediment reincorporation into the reef framework was calculated based off the assumption that $50 \%$ of the parrotfish-derived sediment, and all sediment produced by urchins and internal bioeroders was re-incorporated into void space and accumulated in the reef structure (Perry et al. 2018b). However, these estimates are likely conservative because they do not consider the high levels of suspended non-reef sediment typical of Singapore's waters (e.g. Browne et al. 2015). To account for these sediment inputs, we use existing reef sedimentation rates from four sites-Kusu $\left(39.13 \mathrm{~kg} \mathrm{~m}^{-2}\right.$ $\mathrm{yr}^{-1}$; Browne et al. 2015), Pulau Hantu, Pulau Semakau and Pulau Satumu $\left(18.01,11.44\right.$ and $1.70 \mathrm{~kg} \mathrm{~m}^{-2} \mathrm{yr}^{-1}$, respectively; Dikou and van Woesik 2006). We assume actual deposition of $20 \%$ of the trap measured rate because sediment traps are known to overestimate accumulation (Field et al. 2013; Browne pers. comm), and high tidal flows between Singapore Islands $\left(>1 \mathrm{~m} \mathrm{~s}^{-1}\right.$, Chen et al. 2005) result in significant resuspension of benthic reef sediment.

To estimate differences between calculated RAP and rates of local sea level rise (SLR), we used Singaporespecific altimetry data from Tkalich et al. (2013). Their data estimate rates of SLR for Singapore's offshore islands of $3.0 \pm 1.3 \mathrm{~mm} \mathrm{yr}^{-1}$ between 1993 and 2010, and estimates of future SLR under representative concentration pathways (RCP) $4.5(0.52 \mathrm{~m}$, range: $0.29-0.73)$ and 8.5 (0.74 m, range: $0.45-1.02)$ to represent lower and higher SLR estimates according to IPCC calibrated language (that there is $a \geq 66 \%$ chance that the observed sea level rise 
would fall within these bounds for a given RCP, Cannaby et al. 2016).

\section{Data analysis}

Differences between reef carbonate budgets, including carbonate production, bioerosion, net carbonate budget, and benthic cover and characteristics were investigated using one-way ANOVAs and Tukey HSD post hoc tests to identify differences among reefs using the aov and TukeyHSD functions from the 'stats' package in $\mathrm{R}$ (R Core Team 2018). Net carbonate budget was log + (1-minimum(budget)) transformed, erosion was log transformed, and EAM cover and rugosity square root transformed to meet assumptions of normality and homogeneity of variances. CCA carbonate production did not meet assumptions for ANOVA, so we used a Kruskal-Wallis test and post hoc pairwise Wilcox tests to identify differences using the kruskal.test and pairwise.wilcox.test functions in the 'stats' package in R ( R Core Team 2018). We tested the relationship between coral morphology (branching, encrusting, massive and other-a combination of foliose, plating, submassive and free-living), life-history strategy (competitive, generalist, stress-tolerant and weedy-Darling et al. 2012, Table S1) and total coral cover with net carbonate production using separate linear and mixed effect models using the lmer function from the 'lme4' package (Bates et al. 2015). Rugosity, number of coral genera, and CCA, macroalgal and EAM cover were covariates in each model. The vif function from the 'car' package (Fox and Weisberg 2018) was used to test for collinearity and found all covariates in every model had a vif of $<2.5$. All linear models had a higher level of support than the mixed models, confirmed by Aikake Information Criterion adjusted for small sample sizes (AICc). We used the dredge function from the 'MuMIn' package (Barton 2019) to run all possible combinations of the linear model for each coral grouping schema. All models within 2 AICc of the best fitting model were averaged, and the null model had an AICc at least 40 greater than the full model (Table 1). All analyses were conducted in R 3.6.1 (R Core Team 2018).

\section{Results}

Mean live coral cover varied significantly among reefs (ANOVA; $\mathrm{F}_{6,35}=7.52, p<0.001$ ) and was strikingly lower on Pulau Jong $(7.5 \pm 2.2 \%$; mean \pm 1 SE unless otherwise stated) than all other reefs ( $p<0.001$ for Pulau Satumu, Pulau Hantu and Terumbu Pempang Tengah and $p<0.05$ for Pulau Semakau) with the exception of Kusu $(20.6 \pm 2.9 \%, \quad p=0.115) \quad$ and Sisters' Island
(19.2 $\pm 2.7 \%, p=0.210)$. Terumbu Pempang Tengah and Pulau Satumu were the only two reefs with coral cover greater than $30 \% \quad(33.5 \pm 2.8 \%$; and $34.5 \pm 1.8 \%$ respectively, Fig. $\mathrm{S} 2 \mathrm{a})$. We recorded 41 coral genera (Table S4), with coral generic diversity highest at Pulau Satumu (30 genera) and lowest at Pulau Jong (18 genera). Of these 41 genera, 23 were considered stress-tolerant, 13 generalist, two weedy and two competitive life-history strategies (Table S4). Four genera were present at all reefs Goniopora, Merulina, Pachyseris (all generalists), and Pectinia (weedy), while seven genera were present at only one reef: Acropora, Alveopora, Diploastrea, Fimbriaphyillia, Herpolitha and Leptastrea, all of which are stresstolerant with the exception of Acropora (competitive). Encrusting growth forms were the majority morphology across reefs (mean $8.1 \pm 1.0 \%$ ) except Pulau Hantu and Pulau Semakau where large stands of columnar Goniopora were present. Branching cover was low across all sites (Table 1) and consisted primarily of Hydnophora, Porites and Pocillopora, with Acropora only present at low abuncances at Pulau Satumu.

Crustose coralline algae (CCA) cover was highest at Pulau Jong $(18.7 \pm 1.5 \%)$ and lowest at Pulau Hantu $(0.7 \pm 0.3 \%)$, with an overall mean of $8.5 \pm 1.0 \%$ (Fig. S2b). Mean carbonate production by CCA was relatively low $\left(0.07 \pm 0.01 \mathrm{~kg} \mathrm{CaCO}_{3} \mathrm{~m}^{-2} \mathrm{yr}^{-1}\right)$ and differed between reefs (Kruskal-Wallis; Chi squared $_{6,35}=35.27$, $p<0.01)$. Pulau Jong was the only reef with carbonate production by CCA of higher than $10 \%$ of production by corals $\left(0.11 \pm 0.01 \mathrm{~kg} \mathrm{CaCO}_{3} \mathrm{~m}^{-2} \mathrm{yr}^{-1}\right)$, although there were similar levels of production on Pulau Satumu $\left(0.10 \pm 0.01 \mathrm{~kg} \quad \mathrm{CaCO}_{3} \quad \mathrm{~m}^{-2} \quad \mathrm{yr}^{-1}\right), \quad$ Sisters' $\left(0.09 \pm 0.01 \mathrm{~kg} \mathrm{CaCO}_{3} \mathrm{~m}^{-2} \mathrm{yr}^{-1}\right)$ and Kusu Islands $\left(0.15 \pm 0.02 \mathrm{~kg} \mathrm{CaCO}_{3} \mathrm{~m}^{-2} \mathrm{yr}^{-1}\right)$, despite their lower levels of CCA cover (Fig. S2b, Table S2). Pulau Hantu and Pulau Semakau showed the lowest CCA production compared to all other reefs $(p<0.005)$, with both reefs having $<0.01 \mathrm{~kg} \mathrm{Ca} \mathrm{CO}_{3} \mathrm{~m}^{-2} \mathrm{yr}^{-1}$ carbonate production from CCA (Fig. S3).

There were marked differences in rugosity among reefs (ANOVA; $\mathrm{F}_{6,35}=4.24, p<0.005$ ), with Kusu Island having higher reef complexity than Pulau Satumu ( $p=0.032)$, Sisters' Island $(p=0.032)$, and Pulau Jong $(p<0.001)$. All other reefs apart from Pulau Jong had moderate $(>2)$ rugosity (Fig. S2c). EAM cover was greatest at Pulau Semakau $(39.0 \pm 2.0 \%)$ and lowest at Pulau Jong $(21.8 \pm 1.9 \%) \quad\left(\right.$ ANOVA; $\quad \mathrm{F}_{6,35}=9.43$, $p<0.005$; Fig S2d). EAM cover at Pulau Jong was significantly lower than at all other reefs except Kusu Island (Tukey HSD: Pulau Semakau and Terumbu Pempang Tengah $p<0.001$, Pulau Hantu and Pulau Satumu $p<0.01$, Sisters' Island $p<0.05)$. Kusu Island also showed significantly lower EAM cover than Pulau 
Table 1 Mean cover of hard coral morphological categories at each site (SE)

\begin{tabular}{|c|c|c|c|c|c|c|c|c|}
\hline & $\begin{array}{l}\text { Pulau } \\
\text { Jong }\end{array}$ & $\begin{array}{l}\text { Pulau } \\
\text { Hantu }\end{array}$ & Kusu & $\begin{array}{l}\text { Pulau } \\
\text { Satumu }\end{array}$ & $\begin{array}{l}\text { Pulau } \\
\text { Semakau }\end{array}$ & $\begin{array}{l}\text { Sisters' } \\
\text { Island }\end{array}$ & $\begin{array}{l}\text { Terumbu Pempang } \\
\text { Tengah }\end{array}$ & All reefs \\
\hline Massive & $\begin{array}{l}0.88 \\
\quad(0.57)\end{array}$ & $5.31(0.97)$ & $\begin{array}{l}3.68 \\
(1.37)\end{array}$ & $4.8(2.20)$ & $3.61(0.90)$ & $4.2(1.61)$ & $7.04(1.96)$ & $4.22(0.58)$ \\
\hline Branching & $\begin{array}{l}0.27 \\
\quad(0.27)\end{array}$ & $1.31(0.61)$ & $\begin{array}{l}1.41 \\
(1.10)\end{array}$ & $0.80(0.58)$ & $0.43(0.43)$ & $0.76(0.64)$ & $2.34(2.31)$ & $1.05(0.39)$ \\
\hline Encrusting & $\begin{array}{l}3.49 \\
(0.69)\end{array}$ & $7.74(1.68)$ & $\begin{array}{l}7.74 \\
(2.08)\end{array}$ & $17.4(3.16)$ & $4.88(2.14)$ & $7.77(1.89)$ & $7.59(2.78)$ & $8.09(1.00)$ \\
\hline Other & & & & & & & & $\begin{array}{l}10.57 \\
(1.38)\end{array}$ \\
\hline Foliose & $\begin{array}{l}0.43 \\
\quad(0.27)\end{array}$ & $2.92(1.51)$ & $\begin{array}{l}3.83 \\
(2.91)\end{array}$ & $2.91(1.35)$ & $2.02(0.99)$ & $1.22(0.0 .59)$ & $6.34(2.22)$ & $2.81(0.64)$ \\
\hline Submassive & $\begin{array}{l}0.37 \\
(0.22)\end{array}$ & $0.55(0.31)$ & $\begin{array}{l}0.81 \\
(0.36)\end{array}$ & $1.93(0.77)$ & $2.63(0.96)$ & $1.73(0.71)$ & $0.68(0.43)$ & $1.24(0.35)$ \\
\hline Columnar & 0 & $\begin{array}{l}11.67 \\
(8.30)\end{array}$ & $\begin{array}{l}2.59 \\
(1.53)\end{array}$ & $0.80(0.58)$ & $6.34(5.4)$ & $0.45(0.23)$ & $2.02(0.96)$ & $3.41(1.72)$ \\
\hline Plating & $\begin{array}{l}0.25 \\
\quad(0.21)\end{array}$ & $2.06(1.30)$ & $\begin{array}{l}0.61 \\
(0.49)\end{array}$ & $3.70(1.06)$ & $1.92(0.95)$ & $0.55(0.55)$ & $4.58(1.80)$ & $1.95(0.68)$ \\
\hline Free-living & $\begin{array}{l}0.27 \\
(0.06)\end{array}$ & $0.11(0.11)$ & 0 & $0.63(0.44)$ & $1.21(0.47)$ & $0.35(0.35)$ & $0.06(0.06)$ & $0.35(0.12)$ \\
\hline
\end{tabular}

Italicised 'Other' category consists of the morphologies

Semakau $(p<0.01)$. Macroalgae cover averaged $9.5 \pm 1.1 \%$ across all reefs surveyed and was primarily dominated by Sargassum, and varied among reefs (ANOVA; $\left.\mathrm{F}_{6,35}=10.33, p<0.001\right)$, with Pulau Satumu $(0.9 \pm 0.5 \%)$ having significantly lower cover (Tukey HSD, $p<0.005$ in all cases) than any other reef apart from Pulau Semakau $(4.9 \pm 2.1 \%)$, which only had significantly (TukeyHSD, $p<0.005$ ) lower cover than Pulau Jong $(16.5 \pm 2.8) \%($ Fig S1e).

Gross coral reef carbonate production and bioerosion differed significantly among the seven reefs (Fig. 2a, b). Mean hard coral carbonate production across reefs was $3.67 \pm 0.31 \mathrm{~kg} \mathrm{CaCO}_{3} \mathrm{~m}^{-2} \mathrm{yr}^{-1}$, and was lowest at Pulau Jong $\left(0.96 \pm 0.31 \mathrm{~kg} \mathrm{CaCO} \mathrm{m}^{-2} \mathrm{yr}^{-1}\right)$ and highest at Pulau Satumu (4.82 $\left.\pm 0.72 \mathrm{~kg} \mathrm{CaCO} \mathrm{m}^{-2} \mathrm{yr}^{-1}\right)$. Hard coral carbonate production at Pulau Jong was significantly lower than Pulau Hantu $(p=0.031)$, Terumbu Pempang Tengah $(p=0.011)$, Pulau Semakau $(p=0.007)$ and Pulau Satumu $(p=0.005)$, but not at Sisters' $(p=0.254)$ or Kusu Islands $(p=0.231)\left(\right.$ ANOVA; $\mathrm{F}_{6,35}=4.016, p<0.005$; Fig. 2b). Total mean bioerosion across reefs was $3.1 \pm 0.1 \mathrm{~kg} \mathrm{CaCO} \mathrm{Cm}^{-2} \mathrm{yr}^{-1}$ and varied significantly from $2.3 \pm 0.1$ (Pulau Hantu) to $4.6 \pm 0.3$ (Pulau Satumu) $\mathrm{kg} \mathrm{CaCO} \mathrm{m}^{-2} \mathrm{yr}^{-1}$ (ANOVA; $\mathrm{F}_{6,35}=13.23, p<0.001$; Fig. 2b). Tukey post hoc tests indicated that Pulau Satumu and Kusu Island did not differ from each other $(p=0.630)$, but Pulau Satumu had significantly higher bioerosion than all other reefs $(p<0.001)$, as did Kusu Island (Hantu: $p<0.001$, Pulau Semakau and Pulau Jong: $p<0.0$,
Terumbu Pempang Tengah and Sisters' Island: $p<0.05)$. Internal bioerosion accounted for nearly $70 \%$ of total bioerosion across reefs (Fig. S4). Parrotfish bioerosion exceeded $30 \%$ of total bioerosion at Pulau Satumu and Kusu, while at Pulau Satumu and Terumbu Pempang Tengah, bioerosion by urchins comprised $20-25 \%$ of the total bierosion (Fig. S4).

Of the seven reefs surveyed, three were accretional (Pulau Hantu, Pulau Semakau and Terumbu Pempang Tengah, three were in stasis (i.e. between +1 and $-1 \mathrm{~kg}$ $\mathrm{CaCO}_{3} \mathrm{~m}^{-2} \mathrm{yr}^{-1}$-Pulau Satumu, Sister's Island and Kusu Island) and one reef was erosional (i.e. negative carbonate budget-Pulau Jong). Overall, mean net carbonate production was $0.63 \pm 0.27 \mathrm{~kg} \mathrm{CaCO}_{3} \mathrm{~m}^{-2} \mathrm{yr}^{-1}$, highest at Pulau Semakau (1.97 $\left.\pm 0.41 \mathrm{~kg} \mathrm{CaCO}_{3} \mathrm{~m}^{-2} \mathrm{yr}^{-1}\right)$, and lowest at Pulau Jong $\left(-1.56 \pm 0.29 \mathrm{~kg} \mathrm{CaCO}_{3} \mathrm{~m}^{-2}\right.$ $\mathrm{yr}^{-1}$ ). Pulau Jong was the only reef with a net negative carbonate production, and had significantly lower net production than all other reefs except Kusu Island (ANOVA; $\mathrm{F}_{6,35}=7.168, p<0.001$; TukeyHSD $p<0.001$ for all comparisons apart from Pulau Satumu, $p=0.03$, and Kusu, $p=0.308$ ) (Fig. 2c).

The models that estimated net carbonate budget from coral morphologies were the best performing models (highest mean $R^{2}$ across all models within 2 AICc of the best model) (Table 2). Cover of other (foliose, columnar, submassive and plating forms) and massive coral morphologies had a significant positive relationship with net budget (Figs. 3a and 4b-d). Only the weedy life-history 

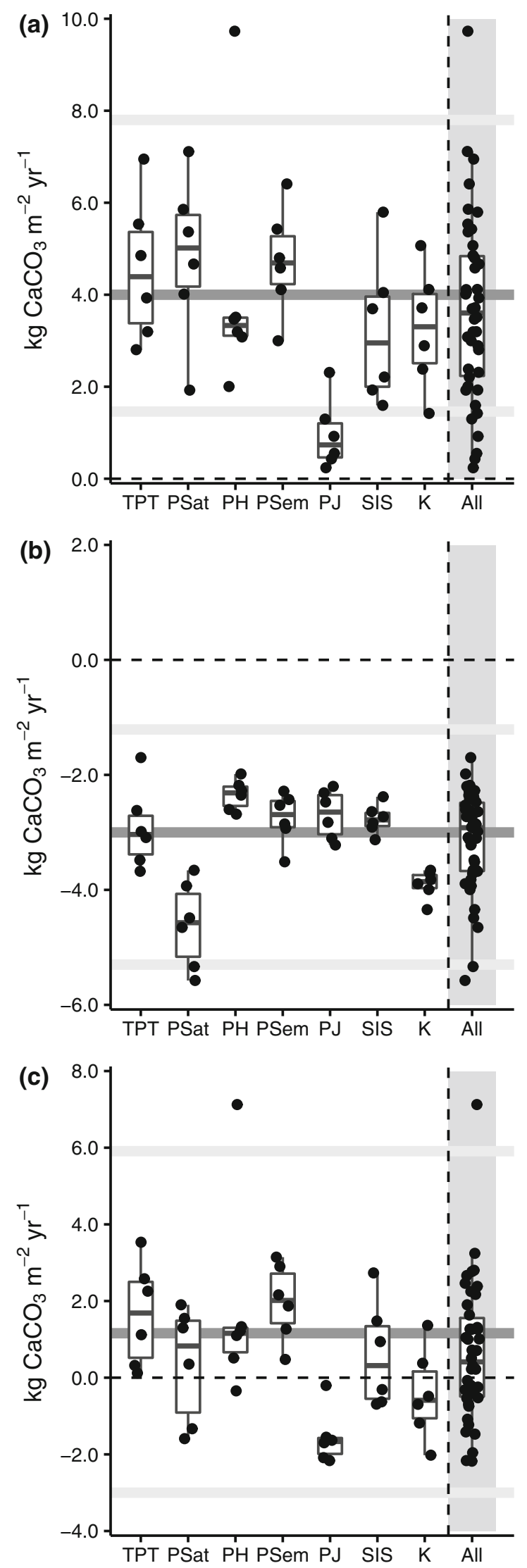

4Fig. 2 Boxplots of net and gross carbonate budget production and bioerosion rates across Singapore corals reefs. Bold black line is median, box limits are inter-quartile range, and whiskers are $1.5 *$ IQR from the box limits. a Bioerosion; b gross hard coral carbonate production; and $\mathbf{c}$ net carbonate production. The grey shaded area represents all reefs combined. The dark grey horizontal lines represents the mean rates for Indo-Pacific reefs with the light grey lines the highest and lowest mean country rates. See Table S5 for exact numbers and countries. TPT-Terumbu Pempang Tengah, PSat-Pulau Satumu, PH-Pulau Hantu; PSem-Pulau Semekau, PJ-Pulau Jong, SIS-Sisters' Island, and K-Kusu Island

category had a significantly positive relationship with net budget (Fig. 3b), with a negative effect of CCA cover on net carbonate budget, which was also seen for the total coral cover only averaged model (Fig. 3c). On transects where encrusting corals were the most dominant, budgets became negative at approximately $20 \%$ coral cover, compared to $\sim 15 \%$ for all transects, or transects where other morphologies were dominant (Fig. 4a). Despite having the second highest cover of any category (Table 1), encrusting coral cover was not associated with any increase in net budget up to $25 \%$ of total benthic cover, in contrast to the positive relationships of coral cover of massive and other morphologies with net budget (Fig. 4b-d). Competitive taxa, and branched morphologies were rare across Singapore reefs, with the proportional contribution to coral production by branched morphologies under $10 \%$ at all but Kusu Island (Fig. 5a), and production by stress-tolerant and generalist corals contributing over $60 \%$ of coral carbonate production at all reefs except the coral depauperate Pulau Jong (Fig. 5b).

Reef accretion potential (RAP) varied considerably across reefs in Singapore ranging from $1.84 \pm 0.28 \mathrm{~mm} \mathrm{yr}^{-1}$ at Pulau Semakau, to $0.09 \pm 0.14 \mathrm{~mm} \mathrm{yr}^{-1}$ at Pulau Jong (mean $1.09 \pm 0.14 \mathrm{~mm} \mathrm{yr}^{-1}$ ), well below contemporary rates of SLR in Singapore of $3.0 \pm 1.3 \mathrm{~mm} \mathrm{yr}^{-1}$ (Fig. 6). When the potential influence of non-reef sediment from anthropogenic activities is taken into account for Kusu Island, Pulau Hantu, Pulau Semakau and Pulau Satumu, the mean RAP for these four reefs was $2.76 \pm 0.35 \mathrm{~mm} \mathrm{yr}^{-1}$ compared with $1.29 \pm 0.20 \mathrm{~mm} \mathrm{yr}^{-1}$ when additional nonreefal sediment supply is not considered. The capacity of Singapore reefs to sustain accretion rates from reef derived production alone is lower than sea level rise (SLR) predicted under both RCP 4.5 and RCP 8.5 (Fig. 6), and this is likely the case for those reefs where non-reef sediment input is considered (Fig. S5). The mean deficit to contemporary SLR across Singapore, when considering only reef derived sediment contributions, was $1.9 \mathrm{~mm} \mathrm{yr}^{-1}$, with the greatest deficit at Pulau Jong $\left(-2.9 \pm 0.1 \mathrm{~mm} \mathrm{yr}^{-1}\right)$, and the lowest at Pulau Semakau 
Table 2 Model statistics for best fitting (within AICc of 2 of the best model) models of net carbonate budget

\begin{tabular}{|c|c|c|c|c|c|c|c|c|c|c|c|}
\hline \multirow{2}{*}{\multicolumn{2}{|c|}{$\begin{array}{l}\text { Model } \\
\text { Morphology }\end{array}$}} & \multicolumn{6}{|c|}{ Variables } & \multirow[t]{2}{*}{ Df } & \multirow[t]{2}{*}{$\mathrm{AICc}$} & \multirow[t]{2}{*}{$w$} & \multirow[t]{2}{*}{$R^{2}$} \\
\hline & & \multicolumn{2}{|l|}{$\begin{array}{l}\text { Massive } \\
\text { coral }\end{array}$} & $\begin{array}{l}\text { Other } \\
\text { morphology }\end{array}$ & $\begin{array}{c}\text { Genera } \\
(\#)\end{array}$ & $\begin{array}{l}\text { Macoralgal } \\
\text { cover }\end{array}$ & $\begin{array}{l}\text { CCA } \\
\text { Cover }\end{array}$ & & & & \\
\hline 1 & & 0.508 & & 0.592 & 0.193 & & & 5 & 26.7 & 0.33 & 0.71 \\
\hline 2 & & 0.453 & & 0.523 & 0.175 & & -0.155 & 6 & 27.2 & 0.25 & 0.72 \\
\hline 3 & & 0.490 & & & 0.158 & -0.102 & & 6 & 28.1 & 0.16 & 0.72 \\
\hline 4 & & 0.489 & & 0.615 & & -0.156 & & 5 & 28.4 & 0.14 & 0.70 \\
\hline 5 & & 0.453 & & 0.545 & & & -0.184 & 5 & 28.6 & 0.13 & 0.70 \\
\hline LHS & \multicolumn{2}{|c|}{ Generalist } & $\begin{array}{l}\text { Stress- } \\
\text { tolerant }\end{array}$ & Weedy & Rugosity & $\begin{array}{l}\text { CCA } \\
\text { cover }\end{array}$ & $\begin{array}{l}\text { Turf } \\
\text { cover }\end{array}$ & & & & \\
\hline 1 & & 0.227 & 0.461 & 0.242 & -0.349 & & 6 & 38.4 & 0.30 & 0.64 \\
\hline 2 & \multicolumn{2}{|c|}{0.174} & 0.247 & 0.418 & 0.193 & -0.298 & & 7 & 38.5 & 0.28 & 0.66 \\
\hline 3 & \multicolumn{2}{|c|}{0.234} & 0.323 & 0.372 & & -0.299 & & 6 & 39.4 & 0.18 & 0.63 \\
\hline 4 & & & 0.221 & 0.461 & 0.259 & -0.267 & 0.127 & 7 & 40.2 & 0.12 & 0.65 \\
\hline 5 & & & & 0.461 & 0.278 & -0.438 & & 5 & 40.2 & 0.12 & 0.60 \\
\hline \multicolumn{2}{|l|}{ All coral } & $\begin{array}{l}\text { Total } \\
\text { coral }\end{array}$ & & $\begin{array}{l}\text { Genera } \\
(\#)\end{array}$ & Rugosity & $\begin{array}{l}\text { Macoralgal } \\
\text { cover }\end{array}$ & $\begin{array}{l}\text { CCA } \\
\text { cover }\end{array}$ & & & & \\
\hline 1 & & 0.541 & & & 0.186 & -0.171 & -0.242 & 6 & 41.0 & 0.71 & 0.56 \\
\hline 2 & & 0.584 & & & 0.159 & & -0.279 & 5 & 42.8 & 0.29 & 0.57 \\
\hline $\begin{array}{l}\text { Null } \\
\text { model }\end{array}$ & & & & & & & & & 71.1 & & \\
\hline
\end{tabular}

$\left(-1.2 \pm 0.3 \mathrm{~mm} \mathrm{yr}^{-1}\right)$. Under RCP 4.5 the mean deficit at the reef level across Singapore is $4.4 \mathrm{~mm} \mathrm{yr}^{-1}$ (range -3.6 to -5.4 ), and under RCP 8.5 the mean deficit is $6.7 \pm 0.9 \mathrm{~mm} \mathrm{yr}^{-1}$ (range -5.9 to -7.6 ). When considering total sediment contribution (reef-derived and nonreef), the mean deficit for the four reefs (Pulau Satumu, Pulau Semakau, Pulau Hantu, Kusu Island) was $0.2 \mathrm{~mm} \mathrm{yr}^{-1}$ (range +1.2 to -1.9 ) for recent historical rates (Fig. S4), $2.7 \mathrm{~mm} \mathrm{yr}^{-1}$ (range 1.3 to 4.3 ) for RCP 4.5 and $5.0 \mathrm{~mm} \mathrm{yr}^{-1}$ (range 3.6 to 6.6 ) for RCP 8.5.

\section{Discussion}

Reef carbonate budgets across reefs in Singapore showed a high degree of variation over relatively small spatial scales $(<10 \mathrm{~km})$, consistent with patterns reported from other Indo-Pacific reef systems (Perry and Morgan 2017; Lange and Perry 2019). Overall, mean net carbonate budgets in Singapore were low compared to other Indo-Pacific reefs at $0.68 \mathrm{~kg} \mathrm{Ca} \mathrm{CO}_{3} \mathrm{~m}^{-3} \mathrm{yr}^{-1}$, although some individual reefs (e.g. Pulau Semakau) were comparable with recent estimates (2013-2017) of Indian Ocean mean net carbonate budget of $\sim 1.5 \mathrm{~kg} \mathrm{Ca} \mathrm{CO} \mathrm{m}^{-2} \mathrm{yr}^{-1}$ (Perry et al. 2018b). This is considerably below net carbonate budgets reported from some isolated Indian Ocean atolls (pre-bleaching) and Micronesia in the Western Pacific (7-14 $\mathrm{kg} \mathrm{CaCO}_{3} \mathrm{~m}^{-2}$ $\mathrm{yr}^{-1}$, Perry et al. 2015b; Perry and Morgan 2017; van Woesik and Cacciapaglia 2018, 2019). However, many of these reefs have since shown dramatic declines in budgets associated with $>60 \%$ post-bleaching reductions in live coral cover (Januchowski-Hartley et al. 2017; Perry and Morgan 2017; Lange and Perry 2019). Previous estimates of coral cover at Pulau Semakau and Pulau Hantu do not show major coral loss over the past three decades (Guest et al. 2016), and in 2012 were only slightly higher than we report here. Mean coral cover was $24.8 \pm 1.8 \%$, and greater than $15 \%$ at all but Pulau Jong, following the 2016 mass coral bleaching event (Toh et al. 2018), compared to $\sim 34.5 \%$ mean coral cover across the same reefs in 2012 (Guest et al. 2016). Further, gross hard coral carbonate production rates at $\sim 3.7 \mathrm{~kg} \mathrm{CaCO}_{3} \mathrm{~m}^{-2} \mathrm{yr}^{-1}$ were not dissimilar to pre-bleaching means across the Indian Ocean of $\sim 4 \mathrm{~kg} \mathrm{CaCO}_{3} \mathrm{~m}^{-2} \mathrm{yr}^{-1}$ (Perry et al. 2018b).

Perry and Alvarez-Filip (2019) suggest that reefs exposed to chronic stressors show a reassembly towards corals tolerant to thermal and physical stressors, associated with lower complexity, slower-growing forms with decreases in carbonate budget outpacing declines in coral cover. Our results, in concert with longer-term evidence of 

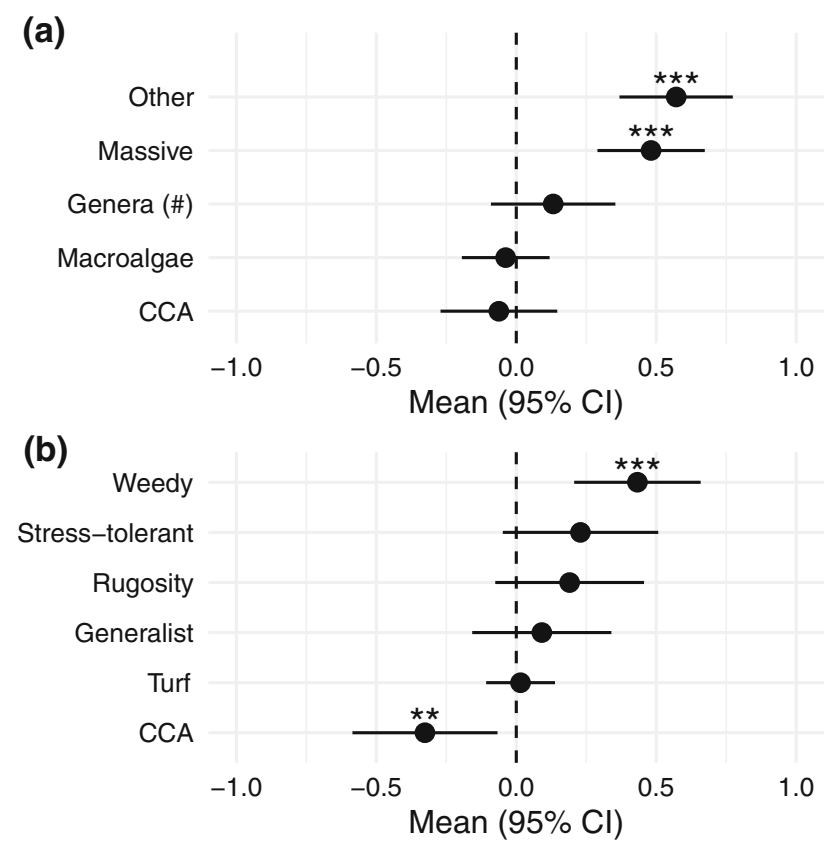

(c)

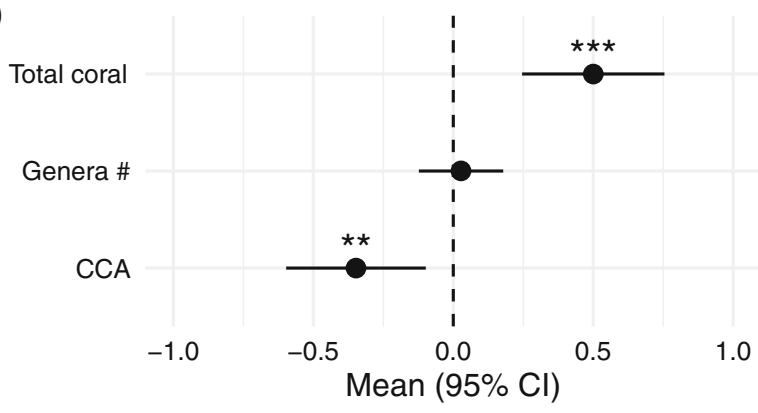

Fig. 3 Forest plots of standardized model coefficients with 95\% CIs for net carbonate budgets using: a coral morphologies; b life-history strategy; and c all coral cover combined. Asterisks indicated significance levels at $*<0.05, * *<0.01, * * *<0.001$

shifts in coral community composition towards slower growing and more stress-tolerant genera (Guest et al. 2016; Heery et al. 2018), suggests this is occurring in Singapore. Mean reef carbonate production rates in Singapore (3-5 kg $\mathrm{CaCO}_{3} \mathrm{~m}^{-2} \mathrm{yr}^{-1}$ ) were associated with $25-35 \%$ coral cover, whereas similar levels of coral cover in the Maldives and East Africa resulted in two to four times these production rates $\left(10-12 \mathrm{~kg} \mathrm{CaCO} \mathrm{m}^{-2} \mathrm{yr}^{-1}\right.$, Perry and Morgan 2017; Perry et al. 2018b). Interestingly, in contrast to previous studies that found increasing coral cover and recruitment with distance from the main port (Dikou and van Woesik 2006; Guest et al. 2016), we found no such pattern for carbonate budget state, with the highest net carbonate budgets at three of the closer islands to the main port (Pulau Hantu, Pulau Semakau and Terumbu Pempang Tengah). This may be due to lower abundances of external bioeroders (particularly parrotfish) at these reefs compared to Pulau Satumu and Kusu Island (Bauman et al. 2017). The low reef carbonate budgets relative to amount of coral cover on Singapore's reefs can be attributed to the dominance of encrusting and laminar growth forms, where growth occurs primarily from the colony edge, rather than across the whole colony (Morgan and Kench 2012). Despite encrusting coral colonies accounting for $20-55 \%$ of live coral cover across reefs, these taxa only produce between 5 and $30 \%$ of the hard coral carbonate in this study. Additionally, the stress-tolerant and generalist species abundant in Singapore usually have slower growth rates (Darling et al. 2012; Tanzil et al. 2013), and the lack of fast-growing, competitive species such as Acropora (which only occurred on one out of 42 transects) further constrain carbonate production rates. Overall, carbonate production rates for the level of hard coral cover in Singapore more closely resemble those of Caribbean reefs, which are dominated by Agaricia, Porites and Siderastrea, where $20-25 \%$ coral cover is associated with net carbonate production of $<2 \mathrm{~kg} \mathrm{CaCO}_{3} \mathrm{~m}^{-2} \mathrm{yr}^{-1}$ (Perry et al. 2015b). This contrasts with most Indo-Pacific reefs where similar levels of coral cover (20-25\%) are associated with 2-6 $\mathrm{kg} \mathrm{CaCO}_{3} \mathrm{~m}^{-2} \mathrm{yr}^{-1}$ net carbonate production, despite having large eroding parrotfish populations (summarized in Perry et al. 2018b). The long-term trend of coral composition on Singapore reefs is a decline in faster growing corals such as Montipora, paucity of competitive branching corals such as Acropora and Pocillipora (Guest et al. 2016; this study) and carbonate production contributions dominated by lower complexity, stress-tolerant and generalist or weedy slower-growing genera such as Pachyseris, Merulina, and Pectinia. This contrasts to reefs elsewhere in the Indo-Pacific, where Acropora, Porites (including branching forms) and Pocillopora dominate carbonate production (Perry et al. 2015b; Perry and Morgan 2017; van Woesik and Cacciapaglia 2018).

Unlike other Indo-Pacific reefs (Januchowski-Hartley et al. 2017; Perry et al. 2015b, 2018a), where erosion by parrotfish can exceed $4 \mathrm{~kg} \mathrm{CaCO}_{3} \mathrm{~m}^{-2} \mathrm{yr}^{-1}$, parrotfish bioerosion was not the major contributor to net rates of bioerosion on Singapore reefs, with maximum recorded rates of $<1.5 \mathrm{~kg} \mathrm{CaCO} \mathrm{m}^{-2} \mathrm{yr}^{-1}$. Shipping activity, coastal development and land reclamation (with over $60 \%$ of reef area lost in Singapore) has resulted in elevated levels of sedimentation and turbidity, which negatively affects herbivorous reef fishes (Cheal et al. 2013). In Singapore, the parrotfish are represented by only a few species, none of which are major bioeroders (Bauman et al. 2017). Scarus ghobban and Scarus rivulatus, the two most abundant parrotfishes in this study, both have low erosional potential (Perry et al. 2018b). Similarly, bioerosion by urchins was locally important on only two reefs (Pulau Satumu and Terumbu Pempang Tengah). The majority of bioerosion on Singapore's reefs is due to combination of internal erosion by macroborers (e.g. sponges and 
(a)

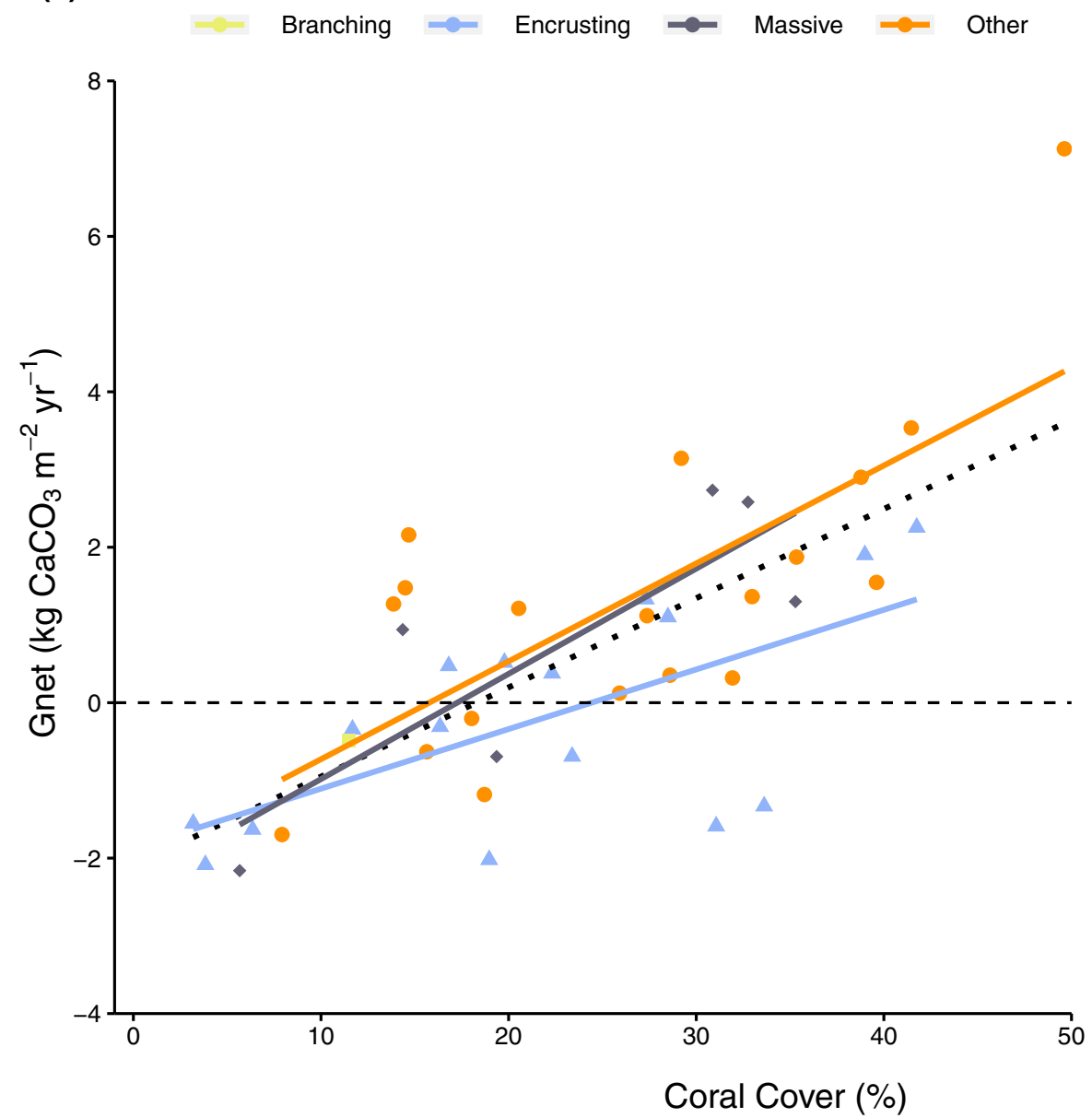

(b)

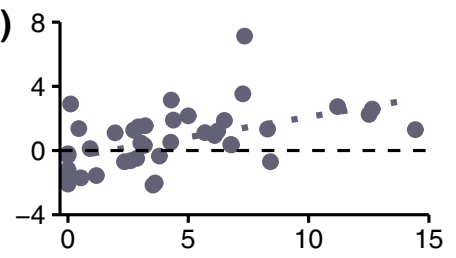

(c)

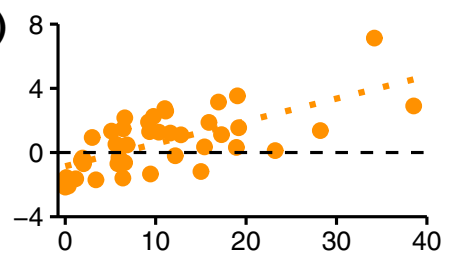

(d)

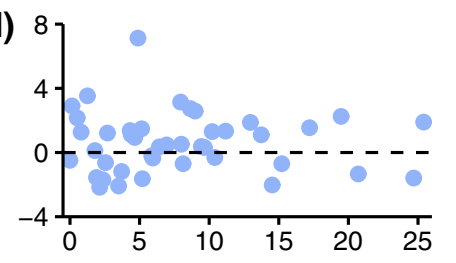

(e)

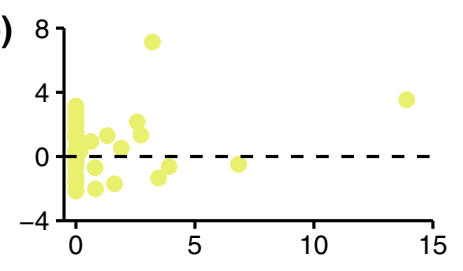

Fig. 4 Relationship between net carbonate budget and a total coral cover, b massive coral cover, c cover of other coral morphologies, $\mathbf{d}$ encrusting coral cover, and e branching coral cover. In a regression

polychaete worms) or by microborers (e.g. cyanobacteria). Rates of internal bioerosion in this study at $\sim 1 \mathrm{~kg} \mathrm{Ca}$ $\mathrm{CO}_{3} \mathrm{~m}^{-2} \mathrm{yr}^{-1}$ were 2 to 4 times higher than reefs elsewhere higher than those reported elsewhere in the IndoPacific (Chazottes et al. 2002; Tribollet and Golubic 2005; Morgan 2014; Enochs et al. 2016), but similar to macrobioerosion reported on reefs in the Gulf of Panama, which experience seasonal upwelling with high nutrients and low $\mathrm{pH}\left(\sim 0.65 \mathrm{~kg} \mathrm{~m}^{-2} \mathrm{yr}^{-1}\right.$, DeCarlo et al. 2015), and nearshore reefs in Maui, Hawaii, which are exposed to waste-water and run-off from agriculture $\left(0.2-1.0 \mathrm{~kg} \mathrm{~m}^{-2}\right.$ $\mathrm{yr}^{-1}$, Prouty et al. 2017). Interestingly, microbioerosion in clear oligotrophic waters of the outer Great Barrier Reefs in the Coral Sea has also been reported in similar range ( $\sim 1 \mathrm{~kg} \mathrm{Ca} \mathrm{CO}_{3} \mathrm{~m}^{-2} \mathrm{yr}^{-1}$-Tribollet et al. 2002), suggesting that both high light and nutrient availability may drive internal erosion. The bioerosion assays used to provide internal bioerosion rates in this manuscript are part of lines are for the different colours represent dominant morphologies within each transect and dotted line is for all transects combined

multi-year study of bioerosion in Singapore to be presented in a future paper.

While the lack of large framework bioeroders such as parrotfish can be expected to slow the breakdown and flattening of reef structure, reefs in Singapore appear to be highly friable, potentially due to the aforementioned high internal bioerosions. This will increase physical framework erosion by ship wakes, storm waves and tidal currents. There is some evidence of this at Pulau Jong, where coral cover in 2017 (this study) declined to $7.5 \%$, compared with over 30\% in 2011 (Bauman et al. 2015), rugosity is low and the cover of rubble is the highest amongst all reefs. On reefs where bioerosion and physical erosion is high, cementation of reef structure by CCA is vital (Manzello et al. 2008; Perry et al. 2008). However, the mean CCA production across Singapore is approximately half the rate observed at most Indo-Pacific reefs (Perry et al. 2018b). Consequently, there is considerable potential for greater declines of complexity with further coral loss, resulting in 


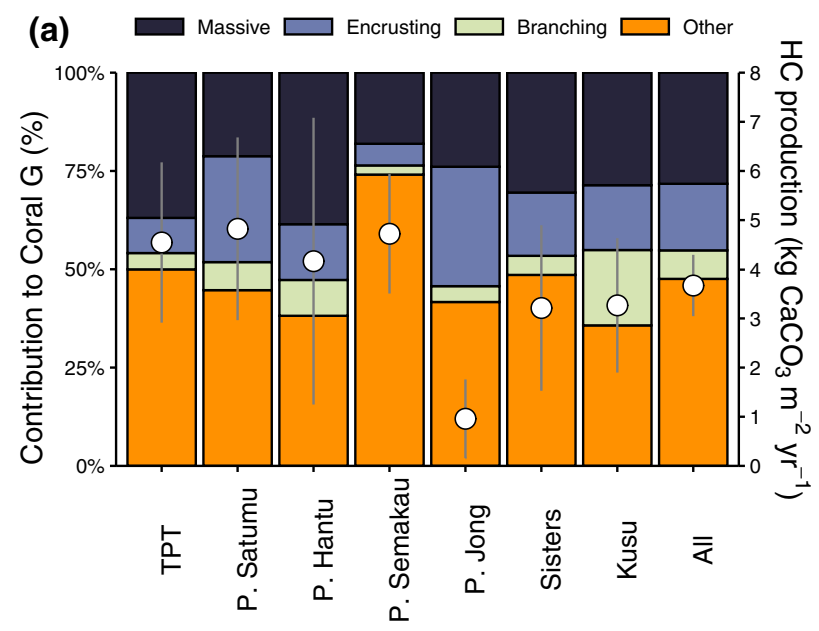

(b)

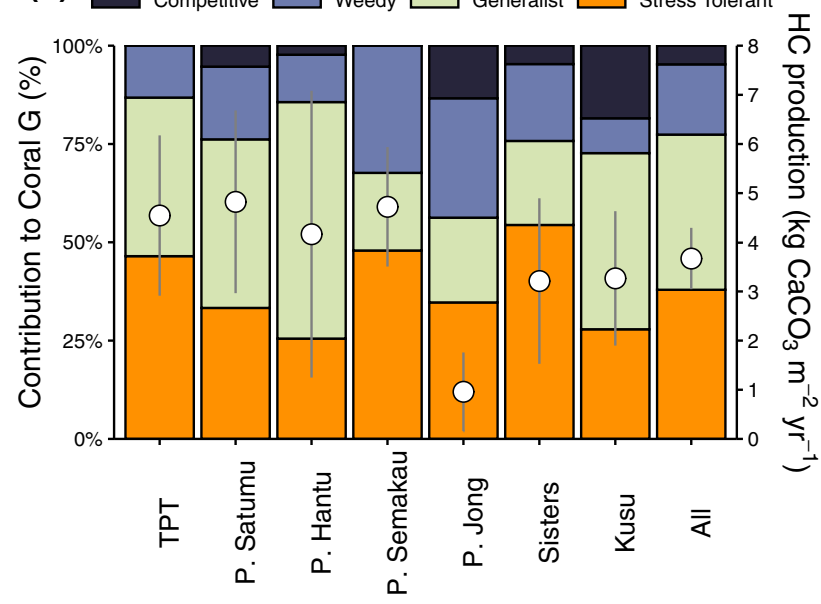

Fig. 5 Contribution of a morphological coral groups, and $\mathbf{b}$ functional coral groups following (Darling et al. 2012) to coral carbonate production, and gross hard coral carbonate production with $95 \%$ confidence intervals (white circles, second $y$ axis)

the reduced ecological niche space and habitat for reef organisms, and concomitant declines in diversity (Graham and Nash 2013).

Singapore's low carbonate budgets, high internal bioerosion and low complexity are reflected in reef accretion potential (RAP) of $1.1 \mathrm{~mm} \mathrm{yr}^{-1}\left(2.8 \mathrm{~mm} \mathrm{yr}^{-1}\right.$ with sediment) substantially lower than recent $\left(\sim 3 \mathrm{~mm} \mathrm{yr}^{-1}\right)$ and future $\left(\sim 4-6 \mathrm{~mm} \mathrm{yr}^{-1}\right)$ sea level rise. Despite our results revealing generally positive rates of ecologically driven vertical accretion of reefs, these rates were considerably lower than observed elsewhere in the Indian Ocean for similar levels of coral cover (Perry et al. 2015a, 2018a; Perry and Morgan 2017; van Woesik and Cacciapaglia 2018; Ryan et al. 2019). While transects with $\sim 50 \%$ coral cover here equated to $4.5 \mathrm{~mm} \mathrm{yr}^{-1} \mathrm{RAP}$, this rate of reef building was achieved at $25-30 \%$ coral cover in the Maldives (pre-bleaching, Perry and Morgan 2017), and East Africa (Perry et al. 2018b). Overall, despite Singapore's reefs having similar mean coral cover to reefs in the IndoPacific in Perry et al. (2018b) pre-bleaching ( 22\% and $20 \%$ respectively), mean RAP in Singapore was only half that across the Indian Ocean (1.2 vs $\left.2.4 \mathrm{~mm} \mathrm{yr}^{-1}\right)$. When compared to reefs with coral communities also dominated by stress-tolerant and generalist species (Mombasa in Kenya, and Pemba in Mozambique; Darling et al. 2013; McClanahan et al. 2014), a similar mean RAP $\left(1.4 \mathrm{~mm} \mathrm{yr}^{-1}\right)$ was found across East African reefs, despite these reefs having coral cover only $75 \%$ of that of Singapore reefs, but similar levels of bioerosion (Perry et al. 2018b). This suggests that while there may be similarities between Singapore and East African reefs in dominance of different components of the coral community, within these components there is substantial variability, and morphological as well as life-history variability needs to be considered.

Due to current plans to reclaim more land around offshore islands in Singapore (Singapore MND 2012), coupled with projections of increased shipping, it is likely that turbidity will increase, and corals will become even more light-limited. The deficit in RAP means Singapore reefs are expected to experience increased water depths over the next $80 \mathrm{yr}$ (up to $80 \mathrm{~cm}$ under RCP8.5). Without action to reduce sedimentation in Singapore, current light levels on these reefs will be further reduced, below that required for coral growth (Morgan et al. 2016). Currently, coral reefs in Singapore occupy a narrow depth range of approximately $4 \mathrm{~m}$ (from 2 to $6 \mathrm{~m}$ ). If levels of turbidity remain the same, increases in sea level rise will see a loss of up to the deepest $80 \mathrm{~cm}$ of these reefs, which will not be compensated by vertical growth. While individual colonies of depth-generalist corals may persist (Chow et al. 2019), the entire reef structure will likely compress to occupy a depth range of $3 \mathrm{~m}$ or less. However, while Singapore reefs appear to be unable to keep up with the rate of SLR through purely biological processes, it is possible that incorporation of sediment of non-reef origin substantially increase RAP. Cores of turbid reefs in Australia have indicated that across the Holocene terrestrial derived sediment can add several $\mathrm{mm} \mathrm{yr}^{-1}$ to reef accretion on inshore reefs (Browne et al. 2013; Perry et al. 2013; Morgan et al. 2016b). Similar rates of framework infill may occur in Singapore, which also has high levels of turbidity and suspended sediments (Dikou and van Woesik 2006; Browne et al. 2015; KM unpubl. data). However, much of this sediment is likely mobilized from dredging and land reclamation activities, and the amount of remobilization and temporal variance in sediment is uncertain due to the paucity of appropriate sedimentation data (Browne et al. 2015; Field et al. 2013). When these sources of sediment were considered, we saw RAP roughly doubled across four 


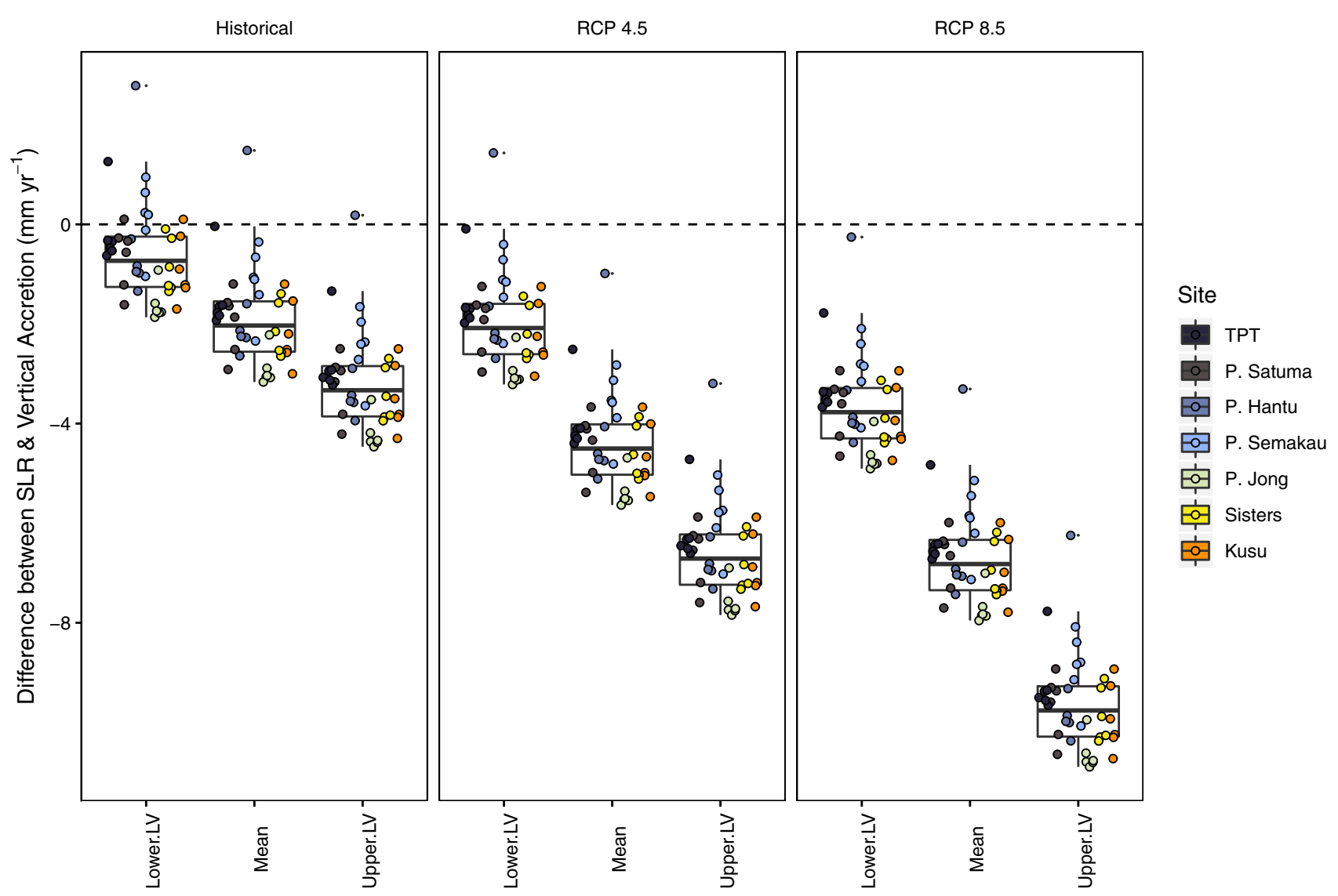

Fig. 6 Difference between reef vertical accretion potential and recent historical, and projected RCP 4.5 and RCP 8.5 sea level rise from 2015 to 2100 . Historical SLR rates are based on altimetry data for the period 1993-2010 (Tkalich et al. 2013); median RCP4.5 and RCP8.5
SLR (and lower and upper limits of likely values of SLR) were obtained from (Cannaby et al. 2016). Colours represent individual reefs. See methods for definition of uncertainty limits reefs of our study, but notably this still results in a deficit compared to rates of sea level rise.

Our work represents the first carbonate budgets that use genera specific growth rates and account for different bioeroding groups for highly urbanized and chronically degraded reefs in the Indo-Pacific. Our results support those of Edinger et al. (2000), which were the first carbonate production and bioerosion rates calculated on chronically polluted reefs, and suggested that these reefs were highly erosional, with low cover of fast-growing Acropora and high internal bioerosion. Extensive land reclamation, dredging of shipping channels and urbanization and transformation of the coastline has led to significant increases in turbidity, and reductions in water quality in Singapore (Heery et al. 2018). Singapore's reefs have undergone a shift in dominant coral types towards stresstolerant, generalist species with slow-growing and lowcomplexity reef structures (Guest et al. 2016). The resulting coral community, while potentially not providing a full suite of coral reef ecosystem functions (Perry and AlvarezFilip 2019), has still resulted in persistent, though potentially senescent (sensu Perry et al. 2008) reef system. More broadly, while Singapore reefs have not necessarily suffered to the same degree as many Indo-Pacific reefs from the acute recent bleaching events, the chronic stressors they have experienced are reflected in coral community composition and carbonate budgets that are consistent with expectations of the future state of resilient reefs (Perry and Alvarez-Filip 2019).

Acknowledgements We thank the crew of Dolphin Explorer and Jenny Fong for field assistance during this work. The Indo-Pacific ReefBudget approach was created by Chris Perry and Ines Lange of the University of Exeter along with Fraser Januchowski-Hartley and we thank them both. This research was supported by the National Research Foundation, Prime Minister's Office, Singapore under its Marine Science Research and Development Programme (MSRDPP03). All research carried out abided by Singapore local laws and was permitted by the Singapore National Park Board (NP/RP17-045). FJH was supported by a Sêr Cymru co-fund fellowship with contributions from the European Research and Development Fund and Welsh 
Government (80761-SU-135). Data and code used for this study can be found at https://github.com/FraserJH/singapore_cbudget.

\section{Compliance with ethical standards}

Conflict of interest On behalf of all authors, the corresponding author states that there is no conflict of interest.

Open Access This article is licensed under a Creative Commons Attribution 4.0 International License, which permits use, sharing, adaptation, distribution and reproduction in any medium or format, as long as you give appropriate credit to the original author(s) and the source, provide a link to the Creative Commons licence, and indicate if changes were made. The images or other third party material in this article are included in the article's Creative Commons licence, unless indicated otherwise in a credit line to the material. If material is not included in the article's Creative Commons licence and your intended use is not permitted by statutory regulation or exceeds the permitted use, you will need to obtain permission directly from the copyright holder. To view a copy of this licence, visit http://creativecommons. org/licenses/by/4.0/.

\section{References}

Barton K (2019) MuMIn: multi-model inference. R package version 1.43.6. https://CRAN.R-project.org/package=MuMIn. Accessed 21 Oct 2019

Bates D, Maechler M, Bolker B, Walker S (2015) Fitting linear mixed-effects models using lme4. J Stat Softw 67:1-48

Bauman AG, Hoey AS, Dunshea G, Feary DA, Low J, Todd PA (2017) Macroalgal browsing on a heavily degraded, urbanized equatorial reef system. Sci Rep 7:8352

Bauman AG, Guest JR, Dunshea G, Low J, Todd PA, Steinberg PD (2015) Coral settlement on a highly disturbed equatorial reef system. PLoS One 10:e0127874

Bongaerts P, Hoeksema BW, Hay KB (2012) Mushroom corals overcome live burial through pulsed inflation. Coral Reefs $31: 399$

Browne NK, Smithers SG, Perry CT (2013) Carbonate and terrigenous sediment budgets for two inshore turbid reefs on the central Great Barrier Reef. Mar Geol 346:101-123

Browne NK, Tay JKL, Low J, Larson O, Todd PA (2015) Fluctuations in coral health of four common inshore reef corals in response to seasonal and anthropogenic changes in water quality. Mar Environ Res 105:39-52

Cacciapaglia C, van Woesik R (2016) Climate-change refugia: shading reef corals by turbidity. Glob Chang Biol 22:1145-1154

Cannaby H, Palmer MD, Howard T, Bricheno L, Calvert D, Krijnen J, Wood R, Tinker J, Bunney C, Harle J, Saulter A, O’Neill C, Bellingham C, Lowe J (2016) Projected sea level rise and changes in extreme storm surge and wave events during the 21st century in the region of Singapore. Ocean Sci 12:613-632

Chazottes V, Le Campion-Alsumard T, Peyrot-Clausade M, Cuet P (2002) The effects of eutrophication-related alterations to coral reef communities on agents and rates of bioerosion (Reunion Island, Indian Ocean). Coral Reefs 21:375-390

Cheal AJ, Emslie M, Aaron MM, Miller I, Sweatman H (2013) Spatial variation in the functional characteristics of herbivorous fish communities and the resilience of coral reefs. Ecol Appl 23:174-188

Chen M, Mural K, Khoo B-C, Lou J, Kumar K (2005) Circulation modelling in the strait of Singapore. J Coast Res 21:960-972
Chou LM, Toh TC, Toh KB, Ng CSL, Cabaitan P, Tun K, Goh E, Afiq-Rosli L, Taira D, Du RCP, Loke HX, Khalis A, Li J, Song T (2016) Differential response of coral assemblages to thermal stress underscores the complexity in predicting bleaching susceptibility. PLoS One 11:e0159755

Chow GSE, Chan YKS, Jain SS, Huang D (2019) Light limitation selects for depth generalists in urbanised reef coral communities. Mar Environ Res 147:101-112

Darling ES, Alvarez-Filip L, Oliver TA (2012) Evaluating life-history strategies of reef corals from species traits. Ecol Lett 15:1378-1386

Darling ES, McClanahan TR, Côté IM (2013) Life histories predict coral community disassembly under multiple stressors. Glob Chang Biol 19:1930-1940

Darling ES, McClanahan TR, Maina J, Gurney GG, Graham NAJ, Januchowski-Hartley F, Cinner JE, Mora C, Hicks CC, Maire E, Puotinen M, Skirving WJ, Adjeroud M, Ahmadia G, Arthur R, Bauman AG, Beger M, Berumen ML, Bigot L, Bouwmeester J, Brenier A, Bridge TCL, Brown E, Campbell SJ, Cannon S, Cauvin B, Chen CA, Claudet J, Denis V, Donner S, Estradivari FN, Feary DA, Fenner D, Fox H, Franklin EC, Friedlander A, Gilmour J, Goiran C, Guest J, Hobbs J-PA, Hoey AS, Houk P, Johnson S, Jupiter SD, Kayal M, Kuo C-Y, Lamb J, Lee MAC, Low J, Muthiga N, Muttaqin E, Nand Y, Nash KL, Nedlic O, Pandolfi JM, Pardede S, Patankar V, Penin L, Ribas-Deulofeu L, Richards Z, Roberts TE, Rodgers KS, Safuan CDM, Sala E, Shedrawi G, Sin TM, Smallhorn-West P, Smith JE, Sommer B, Steinberg PD, Sutthacheep M, Tan CHJ, Williams GJ, Wilson S, Yeemin T, Bruno JF, Fortin M-J, Krkosek M, Mouillot D (2019) Social-environmental drivers inform strategic management of coral reefs in the Anthropocene. Nat Ecol Evol 3:1341-1350

DeCarlo TM, Cohen AL, Barkley HC, Cobban Q, Young C, Shamberger KE, Brainard RE, Golbuu Y (2015) Coral macrobioerosion is accelerated by ocean acidification and nutrients. Geology 43:7-10

Dikou A (2009) Skeletal linear extension rates of the foliose scleractinian coral Merulina ampliata (Ellis \& Solander, 1786) in a turbid environment. Mar Ecol 30:405-415

Dikou A, van Woesik R (2006) Survival under chronic stress from sediment load: spatial patterns of hard coral communities in the southern islands of Singapore. Mar Pollut Bull 52:1340-1354

Dsikowitzky L, Ferse S, Schwarzbauer J, Vogt TS, Irianto HE (2016) Impacts of megacities on tropical coastal ecosystems-the case of Jakarta, Indonesia. Mar Pollut Bull 110:621-623

Edinger EN, Limmon GV, Jompa J, Widjatmoko W, Heikoop JM, Risk MJ (2000) Normal coral growth rates on dying reefs: are coral growth rates good indicators of reef health? Mar Pollut Bull 40:404-425

Enochs IC, Manzello DP, Kolodziej G, Noonan SHC, Valentino L, Fabricius KE (2016) Enhanced macroboring and depressed calcification drive net dissolution at high- $\mathrm{CO}_{2}$ coral reefs. Proc Biol Sci 283:20161742

Erftemeijer PLA, Riegl B, Hoeksema BW, Todd PA (2012) Environmental impacts of dredging and other sediment disturbances on corals: a review. Mar Pollut Bull 64:1737-1765

Field ME, Chezar H, Storlazzi CD (2013) SedPods: a low-cost coral proxy for measuring net sedimentation. Coral Reefs 32:155-159

Fox J, Weisberg S (2018) An R companion to applied regression, 3rd edn. Sage Publications, Thousand Oaks

Graham NAJ, Nash KL (2013) The importance of structural complexity in coral reef ecosystems. Coral Reefs 32:315-326

Guest JR, Baird AH, Maynard JA, Muttaqin E, Edwards AJ, Campbell SJ, Yewdall K, Affendi YA, Chou LM (2012) Contrasting patterns of coral bleaching susceptibility in 2010 suggest an adaptive response to thermal stress. PLoS One 7:e33353 
Guest JR, Tun K, Low J, Vergés A, Marzinelli EM, Campbell AH, Bauman AG, Feary DA, Chou LM, Steinberg PD (2016) 27 years of benthic and coral community dynamics on turbid, highly urbanised reefs off Singapore. Sci Rep 6:36260

Heery EC, Hoeksema BW, Browne NK, Reimer JD, Ang PO, Huang D, Friess DA, Chou LM, Loke LHL, Saksena-Taylor P, Alsagoff N, Yeemin T, Sutthacheep M, Vo ST, Bos AR, Gumanao GS, Syed Hussein MA, Waheed Z, Lane DJW, Johan O, Kunzmann A, Jompa J, Suharsono TD, Bauman AG, Todd PA (2018) Urban coral reefs: degradation and resilience of hard coral assemblages in coastal cities of East and Southeast Asia. Mar Pollut Bull 135:654-681

Hoey AS, Bellwood DR (2009) Limited functional redundancy in a high diversity system: single species dominates key ecological process on coral reefs. Ecosystems 12:1316-1328

Januchowski-Hartley FA, Graham NAJ, Wilson SK, Jennings S, Perry CT (2017) Drivers and predictions of coral reef carbonate budget trajectories. Proc Biol Sci 284:20162533

Kennedy EV, Perry CT, Halloran PR, Iglesias-Prieto R, Schönberg CHL, Wisshak M, Form AU, Carricart-Ganivet JP, Fine M, Eakin CM, Mumby PJ (2013) Avoiding coral reef functional collapse requires local and global action. Curr Biol 23:912-918

Lange ID, Perry CT (2019) Bleaching impacts on carbonate production in the Chagos Archipelago: influence of functional coral groups on carbonate budget trajectories. Coral Reefs 38:619-6234

Low JKY, Fong J, Todd PA, Chou LM, Bauman AG (2019) Seasonal variation of Sargassum ilicifolium (Phaeophyceae) growth on equatorial coral reefs. J Phycol 55:289-296

Manzello DP, Kleypas JA, Budd DA, Eakin CM, Glynn PW, Langdon C (2008) Poorly cemented coral reefs of the eastern tropical Pacific: possible insights into reef development in a high- $\mathrm{CO}_{2}$ world. Proc Natl Acad Sci U S A 105:10450-10455

McClanahan TR, Ateweberhan M, Darling ES, Graham NAJ, Muthiga NA (2014) Biogeography and change among regional coral communities across the Western Indian Ocean. PLoS One 9:e93385

Morgan K (2014) A calcium carbonate budget of a Maldivian reef platform. PhD thesis, University of Auckland, p 204

Morgan KM, Kench PS (2012) Skeletal extension and calcification of reef-building corals in the central Indian Ocean. Mar Environ Res 81:78-82

Morgan KM, Perry CT, Smithers SG, Johnson JA, Daniell JJ (2016a) Evidence of extensive reef development and high coral cover in nearshore environments: implications for understanding coral adaptation in turbid settings. Sci Rep 6:29616

Morgan KM, Perry CT, Smithers SG, Johnson JA, Gulliver P (2016b) Transitions in coral reef accretion rates linked to intrinsic ecological shifts on turbid-zone nearshore reefs. Geology 44:995-998

Morgan KM, Perry CT, Johnson JA, Smithers SG (2017) Nearshore turbid-zone corals exhibit high bleaching tolerance on the Great Barrier Reef following the 2016 ocean warming event. Front Ma Sci 4:224

Ng CSL, Lim JX, Sam SQ, Kikuzawa YP, Toh TC, Wee TW, Sim WT, Ng NK, Huang D, Chou LM (2019) Variability in skeletal bulk densities of common hard corals in Southeast Asia. Coral Reefs 38:1133-1143

Perry CT, Morgan KM (2017) Post-bleaching coral community change on southern Maldivian reefs: is there potential for rapid recovery? Coral Reefs 36:1189-1194

Perry CT, Alvarez-Filip L (2019) Changing geo-ecological functions of coral reefs in the Anthropocene. Funct Ecol 33:976-988

Perry CT, Spencer T, Kench PS (2008) Carbonate budgets and reef production states: a geomorphic perspective on the ecological phase-shift concept. Coral Reefs 27:853-866
Perry CT, Smithers SG, Gulliver P (2013) Rapid vertical accretion on a "young" shore-detached turbid zone reef: offshore Paluma Shoals, central Great Barrier Reef, Australia. Coral Reefs 32:1143-1148

Perry CT, Lange I, Januchowski-Hartley FA (2018a) ReefBudget: methodology (Indo-Pacific version). https://geography.exeter.ac. uk/reefbudget/indopacific/. Accessed 28 Jan 2019

Perry CT, Murphy GN, Graham NAJ, Wilson SK, JanuchowskiHartley FA, East HK (2015a) Remote coral reefs can sustain high growth potential and may match future sea-level trends. Sci Rep 5:18289

Perry CT, Murphy GN, Kench PS, Edinger EN, Smithers SG, Steneck RS, Mumby PJ (2014) Changing dynamics of Caribbean reef carbonate budgets: emergence of reef bioeroders as critical controls on present and future reef growth potential. Proc Biol Sci 281:20142018

Perry CT, Steneck RS, Murphy GN, Kench PS, Edinger EN, Smithers SG, Mumby PJ (2015b) Regional-scale dominance of nonframework building corals on Caribbean reefs affects carbonate production and future reef growth. Glob Chang Biol 21:1153-1164

Perry CT, Alvarez-Filip L, Graham NAJ, Mumby PJ, Wilson SK, Kench PS, Manzello DP, Morgan KM, Slangen ABA, Thomson DP, Januchowski-Hartley F, Smithers SG, Steneck RS, Carlton R, Edinger EN, Enochs IC, Estrada-Saldívar N, Haywood MDE, Kolodziej G, Murphy GN, Pérez-Cervantes E, Suchley A, Valentino L, Boenish R, Wilson M, Macdonald C (2018b) Loss of coral reef growth capacity to track future increases in sea level. Nature 558:396-400

Prouty NG, Cohen A, Yates KK, Storlazzi CD, Swarzenski PW, White D (2017) Vulnerability of coral reefs to bioerosion from land-based sources of pollution: coral reef vulnerability. J Geophys Res C Oceans 122:9319-9331

R Core Team (2018) R: a language and environment for statistical computing. R Foundation for Statistical Computing, Vienna, Austria. https://www.R-project.org/

Ryan EJ, Hanmer K, Kench PS (2019) Massive corals maintain a positive carbonate budget of a Maldivian upper reef platform despite major bleaching event. Sci Rep 9:6515

Singapore MND (2012) A high quality living environment for all Singaporeans: land use plan to support Singapore's future population. https://www.ura.gov.sg/Corporate/Planning/MasterPlan. Accessed 26 Oct 2019

Small C, Nicholls RJ (2003) A global analysis of human settlement in coastal zones. J Coast Res 19:584-599

Smith SV, Kinsey DW (1976) Calcium carbonate production, coral reef growth, and sea level change. Science 194:937-939

Sully S, van Woesik R (2020) Turbid reefs moderate coral bleaching under climate-related temperature stress. Glob Chang Biol 26:1367-1373

Tanzil JTI, Brown BE, Dunne RP, Lee JN, Kaandorp JA, Todd PA (2013) Regional decline in growth rates of massive Porites corals in Southeast Asia. Glob Chang Biol 19:3011-3023

Tkalich P, Vethamony P, Luu Q-H, Babu MT (2013) Sea level trend and variability in the Singapore strait. Ocean Sci 9:293-300

Todd PA, Heery EC, Loke LHL, Thurstan RH, Kotze DJ, Swan C (2019) Towards an urban marine ecology: characterizing the drivers, patterns and processes of marine ecosystems in coastal cities. Oikos 128:1215-1242

Toh TC, Huang D, Tun K, Chou LM (2018) Summary of coral bleaching from 2014 to 2017 in Singapore. In: Chou KTT (ed) Status of coral reefs in East Asian seas region: 2018. Ministry of the Environment of Japan and Japan Wildlife Research Center, Tokyo, pp 21-23

Tribollet A, Golubic S (2005) Cross-shelf differences in the pattern and pace of bioerosion of experimental carbonate substrates 
exposed for 3 years on the northern Great Barrier Reef, Australia. Coral Reefs 24:422-434

Tun KPP (2012) Optimisation of reef survey methods and application of reef metrics and biocriteria for the monitoring of sedimentimpacted reefs. PhD thesis, National University of Singapore, p 179

van Woesik R, Cacciapaglia CW (2018) Keeping up with sea-level rise: carbonate production rates in Palau and Yap, western Pacific Ocean. PLoS One 13:e0197077

van Woesik R, Cacciapaglia CW (2019) Carbonate production of Micronesian reefs suppressed by thermal anomalies and Acanthaster as sea-level rises. PLoS One 14:e0224887
Wilson SK, Bellwood DR, Choat JH, Furnas MJ (2003) Detritus in the epilithic algal matrix and its use by coral reef fishes. Oceanogr Mar Biol Annu Rev 41:279-310

Wong JSY, Chan YKS, Ng CSL, Tun KPP, Darling ES, Huang D (2018) Comparing patterns of taxonomic, functional and phylogenetic diversity in reef coral communities. Coral Reefs 37:737-750

Publisher's Note Springer Nature remains neutral with regard to jurisdictional claims in published maps and institutional affiliations. 